\title{
Formation of volatile compounds in kefir made of goat and sheep milk with high polyunsaturated fatty acid content
}

\author{
D. Cais-Sokolińska, ${ }^{*}$ J. Wójtowski, $\dagger^{1}$ J. Pikul, ${ }^{*}$ R. Danków, ${ }^{*}$ M. Majcher, ${ }^{*} J$. Teichert, ${ }^{*}$ and E. Bagnickał \\ *Department of Dairy Technology, Faculty of Food Science and Nutrition, Poznań University of Life Sciences, Wojska Polskiego 31, \\ 60-624 Poznań, Poland \\ †Department of Small Mammals Breeding and Raw Material of Animal Origin, Poznań University of Life Sciences, Słoneczna 1, \\ 62-002 Suchy Las, Poland \\ łInstitute of Genetics and Animal Breeding of the Polish Academy of Sciences in Jastrzębiec, Postępu 36A, 05-552 Magdalenka, Poland
}

\begin{abstract}
This article explored the formation of volatile compounds during the production of kefir from goat and sheep milks with high polyunsaturated fatty acids (PUFA) as a result of feeding animals forage supplemented with maize dried distillers grains with solubles (DDGS). The increased PUFA content of the goat and sheep milks resulted in significant changes to the fermentation process. In particular, apart from an increase in the time taken to ferment sheep milk, fermentation yielded less 2,3-butanedione. The highest quantities of this compound were assayed in kefir produced from goat milk with an increased content of PUFA. An increase of PUFA significantly elevated ethanal synthesis during lactose-alcohol fermentation of sheep milk. Neither the origin of milk (sheep or goat) nor the level of PUFA had any statistical effect on the amount of ethanal assayed during the fermentation of milk and within the finished product. The proportion of $\mathrm{L}(+)$-lactic acid was higher in kefirs produced using goat milk compared with sheep milk and did not depend on the content of PUFA in milk fat. The content of PUFA had a significant effect on the aroma profile of the resulting kefirs. An increase in PUFA content resulted in the loss of whey aroma in goat milk kefirs and the animal odor in sheep milk kefirs, and a creamy aroma became more prevalent in kefirs made from sheep milk.
\end{abstract}

Key words: goat and sheep milk, fermentation, kefir, polyunsaturated fatty acids, volatile compounds

\section{INTRODUCTION}

The promotion of a healthy human nutrition model requires the search for optimal methods to produce

Received February 7, 2015.

Accepted June 15, 2015.

${ }^{1}$ Corresponding author: jacwojto@gmail.com salutogenic (i.e., supporting health) food. Modern consumers are aware of product quality and contents, and consumers increasingly look for "functional foods"foods containing nutrients that, in addition to their traditional functions, have compounds favorable for health (Duggan et al., 2002).

Ruminant milk, especially ovine and caprine milk, is a rich source of biologically active isomers of oleic acid and conjugated linoleic acid (Bergamo et al., 2003; Haenlein, 2004; Park et al., 2007). Two CLA isomers are considered biologically active agents that have beneficial effects on human health: cis-9,trans-11, and trans-10, cis-12 C18:2.

The main source of biologically active compounds derived from fat present in the milk of ruminants is the unsaturated fatty acids. These compounds are a substrate for the biohydrogenation process as well as for de novo synthesis of fatty acids in the mammary gland (Dewhurst et al., 2001; Chilliard et al., 2007). An increased supply of these compounds in the feed ration intensifies biohydrogenation. Such intensification leads to the creation of a greater number of substrates for de novo synthesis (Kim et al., 2002).

Feed components with the potential to stimulate biohydrogenation and de novo synthesis are used in the production process of biofuels, such as oilseed meal (Anderson et al., 2006; Kleinschmit et al., 2007; Janicek et al., 2008). Distillers solubles are obtained during production of ethanol. Due to production scope, content, and nutritional qualities, distillers solubles are gaining importance in livestock animal feed. The most frequently produced are dried full solubles containing postfermentation solid and liquid fractions. These solubles are referred to as distillers dried grains with solubles (DDGS; Schauer et al., 2008).

Much research has been devoted to DDGS applications in cattle feed, mainly dairy cattle. However, less has been published on using DDGS in feed for small ruminants. The few publications that are available on this subject are mainly about feed for fattening sheep 
(Estrada-Angulo et al., 2008); there remains a lack of available literature on using DDGS in dairy goat feed.

The sensory properties of milk are affected by concentrations of individual volatile organic compounds (Coppa et al., 2011; Villeneuve et al., 2013). In relation to organoleptic properties, unsaturated FA could be used as precursors of lactones found in milk (Urbach, 1990). Increasing the PUFA concentration in milk fat could also increase the concentration of PUFA oxidation and degradation products. In this regard, $\beta$-oxidation at the double bonds can lead to straight-chain aldehydes and ketones, which may be converted to the corresponding alcohols under reducing conditions (Nursten, 1997). Moreover, concentrations of major FA can influence the physical properties of milk fat in relation to the individual melting point of these FA (Couvreur et al., 2006; Hurtaud et al., 2007).

In the development of dairy products such as kefir, the following play a crucial role: chemical composition of the processed milk, type and quantity of starter cultures, temperature- and time-related conditions of fermentation, and amount of chilling. Substrates of the components that form the aroma of fermented products can be proteins, fats, and especially sugars. About 100 different chemical compounds constituting the aroma of dairy products have already been isolated. Only a few of these compounds, however, are responsible for the typical and expected aroma of a particular product.

Few scientific publications have reported the profile of compounds constituting the aroma of fermented milk. The majority of the research described is related to products that have undergone a long ripening process (e.g., rennet cheeses). In long-ripening products, a long production process is needed (i.e., fermentation) as well as further ripening and a higher concentration of volatile compounds. Because of this long process, it is easier to investigate the profile of compounds in long-ripening products than in fermented milk. Most researchers involved in fermented milk studies believe the main components of fermented milk aroma are 2,3-butanodiol and ethanal and, to a lesser extent, formic acid, acetic acid, propanoic acid, propionic acid, butyric acid, and carbonylic compounds (acetone, acetoin). The flavoraromatic desirability of fermented milk depends not only on the content of these compounds but also their relative proportions. According to the parameters of the fermentation processes, the following compounds evolve: butyric acid, isovaleric acid, capronic acid, and acetone. The enzymatic activity of $\mathrm{pH}$-dependent bacteria affects the quantity of the synthesized alcohols. As the milk $\mathrm{pH}$ is lowered by fermentation, the enzyme activities of alcohol dehydrogenase, glutamic dehydro- genase, and $\alpha$-keto-acid dehydrogenase of the lactic bacteria decrease (Helinck et al., 2004).

Bendall (2001) used gas chromatography-olfactometry to examine the effects of cows fed with feed containing $25 \%$ maize silage, $19.5 \%$ grass silage, $7.5 \%$ hay, $10 \%$ whole cottonseed, and $38 \%$ concentrate, which included maize grain, barley, soybean, fishmeal, vegetable oil, protected fat, corn gluten, molasses, minerals, and vitamins. He identified more than 71 chemical compounds associated with the aroma of the obtained milk. He also noted that aroma compounds with the highest nasal impact frequency (NIF) values can be divided into 5 chemical classes: nitrogen heterocycles, linolenic acid oxidation products, $\gamma$-lactones, phenolics, and phytol derivatives. Linolenic acid oxidation products (particularly octa-1,cis-5-dien-3-one, hept-cis-4-enal, and hex-cis-3-enal) were more important in nasal impact frequency profiles than linoleic acid oxidation products (oct-1-en-3-one and non-1-en-3-one). So far, no studies have been conducted to assess the aroma profile of sheep and goat milks containing a higher content of polyene acids. The few studies carried out to date have focused on raw and pasteurized drinking milk (CaisSokolińska et al., 2011). It was concluded that a higher concentration of PUFA in raw milk affects the milk aroma and that aroma changes after thermal treatment (Cais-Sokolińska et al., 2011). No studies have been done on the influence of further technological activities, including fermentation, on the profile changes of volatile compounds of small ruminant milk.

Based on these results, we hypothesized that the synthesis of aromagenic compounds can be correlated with the volume of precursors in the processed milk; that is, the availability of pyruvate resulting from citrate fermentation, whose quantity in milk depends on the way animals are fed and on the activity of the citrate permease created by lactic acid bacteria (LAB). As result of the enzymatic activity and thermal treatment of milk, other components of milk can be created; that is, butyric acid, hexanoic acid, caprylic acids, and ketones. They are product of the decomposition of FA and AA released from proteins during milk fermentation (Beshkova et al., 2003).

The aims of this study were (1) to define the influence of the DDGS feed additive on FA profiles, especially on the concentration of polyene FA in sheep and goat milks; (2) to assess the volume of aroma substrates and compounds stimulating the metabolic activity of LAB in processed sheep and goat milk (the milk had a higher PUFA concentration); the changes of the milk acid content and the degree of attenuation of lactose were taken into consideration in the assessment; and 
(3) to assess the process of fermentation and synthesis of the aroma components of goat and sheep milk kefir.

\section{MATERIALS AND METHODS}

The protocol of this study was approved by the relevant ethical committee related to the institution in which it was performed, and animal care was in accordance with the EU Directive 2010/63/EU. The milk in this study was collected from ewes from the Polish Dairy sheep line 05 (Barczak et al., 2009) and from goats of the Polish White Improved breed. The animals were kept in an indoor housing system on a goat and sheep farm in western Poland. Goats and ewes were randomly allocated from a herd of female goats and ewes into a control goat group $(\mathrm{n}=16)$, experimental goat group (DDGS group; $\mathrm{n}=16$ ), control ewe group $(\mathrm{n}=16)$, and experimental ewe group (DDGS; $\mathrm{n}=16)$ The goats had an average BW of $56 \mathrm{~kg}( \pm 4 \mathrm{~kg})$ and were aged between 3 and 4 yr (during their second and third lactation). The average BW of ewes was $60 \mathrm{~kg}$ $( \pm 5.5 \mathrm{~kg})$ and they were 3,4 , and 5 yr of age.

Both species of animals in this experiment were fed either a basal diet (control group) or the basal diet plus $12 \mathrm{~g}$ per $100 \mathrm{~g}$ of DDGS maize concentrate DM (experimental group). The diets were formulated to meet the animals' nutrient requirements: 1.61 UFM (unit for milk production) and $157 \mathrm{~g}$ of PDI (protein truly digestible in the small intestine). The software INWAR version 1.0 and INRAtion version 2.63 (1998; French National Institute for Agricultural Research, Clermont-Ferrand, France) were used for these calculations. The amount of DDGS offered was established based on series of previous experiments of supplementation to dairy ewe diets, in which 10,12, or $20 \mathrm{~g} / 100 \mathrm{~g}$ of Camelina sativa cake (CSC) improved milk FA composition (Cais-Sokolińska et al., 2011; Szumacher-Strabel et al., 2011).

During the experiment, ewes and goats were fed $1 \mathrm{~kg}$ of concentrate and $2.4 \mathrm{~kg}$ of alfalfa/grass silage and meadow hay (DM basis) per ewe and doe per day. Concentrates were individually fed in 2 equal portions during milking, and chopped alfalfa hay was provided in box feeders twice daily (0700 and $1800 \mathrm{~h}$ ). Animals had free access to water and a mineral saltlick.

The does and ewes were at the same stage of lactation. Until d 89 of lactation, all animals were fed the basal diet. Starting from d 90 of lactation and for the next $30 \mathrm{~d}$, the goats and ewes in the control groups continued to receive the basal diet, whereas the animals in the experimental group (DDGS) were fed the experimental diet; that is, the basal diet plus $12 \mathrm{~g} / 100$ $\mathrm{g}$ of DDGS in concentrate DM. After a $30-\mathrm{d}$ period of adaptation to the experimental diet, every other day, from d 120 to 132 of lactation, individual milk samples were collected during the morning and evening milking $(2 \times 250 \mathrm{~mL})$ from all goats and ewes. Animals were machine milked twice a day. Daily samples of milk from individual animals were prepared by mixing milk from the morning and evening milkings (1:1). Subsequently, daily milk samples were poured into bulk tanks, separated for control and DDGS groups, and mixed. In this way, 12 samples of bulk tank milk from goats ( 6 for control and 6 for DDGS group) and 12 samples of bulk tank milk from ewes (6 for control and 6 for DDGS group) were obtained for chemical analysis and for kefir production.

Samples of concentrates were collected every week and analyzed according to AOAC International (2007) for DM (method no. 934.01), ash (method no. 942.05), and crude fiber (method no. 978.10). Crude protein was determined with the use of a Kjel-Foss Automatic 16210 analyzer (Foss Electric, Hillerød, Denmark; AOAC International, 2007; method no. 976.05), whereas crude fat was tested with a Soxtec System HT analyzer (Tecator AB, Hoganas, Sweden; method no. 973.18). Neutral detergent fiber was determined by the method of Van Soest et al. (1991). Organic matter was calculated as the difference between DM and ash. The basic composition and nutritive value of used concentrates are given in Table 1.

The raw whole goat and sheep milks were pasteurized at $72^{\circ} \mathrm{C}$ and kept for $15 \mathrm{~s}$ in a plate pasteurizer. The fermentation process of milk was initiated by the addition of a mixture of mesophilic strains of lactic acid

Table 1. Ingredients, basic composition, and nutritive value of concentrates

\begin{tabular}{lcc}
\hline & \multicolumn{2}{c}{ Group } \\
\cline { 2 - 3 } Item & Control & DDGS \\
\hline Ingredient (g/kg of DM) & 700 & 700 \\
Wheat & 80 & 80 \\
Wheat bran & 200 & 80 \\
Rapeseed extracted meal & 0 & 120 \\
Maize dried distillers grains with solubles & 20 & 20 \\
Minerals and vitamins & & \\
Basic composition (g/100 g) & 88.49 & 88.60 \\
DM & 83.25 & 83.60 \\
OM & 5.24 & 5.00 \\
Crude ash & 17.20 & 16.20 \\
CP & 5.13 & 5.10 \\
Crude fiber & 3.46 & 2.60 \\
Crude fat & 15.39 & 15.84 \\
NDF & & \\
Nutritive value & & \\
UFM & 0.99 & 1.11 \\
PDIN (g) & 115.4 & 103.0 \\
PDIE (g) & 106.8 & 102.0 \\
\hline
\end{tabular}

${ }^{1} \mathrm{UFM}=$ unit for milk production $\left(1,700 \mathrm{kcal}\right.$ of $\left.\mathrm{NE}_{\mathrm{L}}\right)$ per $\mathrm{kg}$ of $\mathrm{DM}$; PDIN $=$ protein truly digestible in the small intestine depending on $\mathrm{NH}_{3}-\mathrm{N}$ per $\mathrm{kg}$ of DM; PDIE = protein truly digestible in the small intestine depending on energy amount per $\mathrm{kg}$ of $\mathrm{DM}$. 
bacteria. A strain under the joint trading code of 75106 from Abiasa Inc. (Quebec, Canada) collection was used.

The starter culture (a commercial product) was introduced in a lyophilized form at a level of 30 activity units $(7.5 \mathrm{~g})$ to $100 \mathrm{~L}$ of milk, and incubation was carried out at $22^{\circ} \mathrm{C}$. The dose of introduced cultures was selected so that the end-point of the fermentation would be a product with a $\mathrm{pH}$ value of 4.6. Milk was fermented at $22^{\circ} \mathrm{C}$ to reach a titratable acidity equal to $31^{\circ} \mathrm{SH}$ (degrees Soxhlet-Henkel). Next, the temperature was lowered to $15 \pm 1^{\circ} \mathrm{C}$ at which the kefir was portioned into polystyrene cups. The kefirs were poured into polystyrene packages (capacity of $150 \mathrm{~g}$ ) and were then cooled to $5 \pm 1^{\circ} \mathrm{C}$, which completed the fermentation process. The kefirs were tested $48 \mathrm{~h}$ after the end of the fermentation process.

Milk and kefir samples $(10 \mathrm{~mL})$ after extraction were analyzed for FA profiles using a gas chromatograph (Varian Star CP 3800) fitted with a flame-ionization detector and a 100-m fused-silica capillary column (0.25 mm i.d.), coated with $0.2 \mu \mathrm{m}$ CP-Sil 88 (Chrompack, Varian, Middelburg, the Netherlands). Nonadecanoic acid $\left(\mathrm{C}_{19: 0}\right.$, Sigma-Aldrich, St Louis, MO) was used as the internal standard. Observed peaks were identified by the comparison of retention times with appropriate FAME standards (37 FAME Mix, Supelco, Poole, UK; CLA; Supelco). Moreover, CLA peaks were identified by comparison with retention times of the reference standard (CLA methyl esters, a mixture of cis and trans-9,11 and 10,12 octadecadienoic acid methyl esters; Sigma-Aldrich) and according to Collomb and Bühler, (2000), using a Varian Workstation (version 5.31).

Determination of the 2,3-butanedione and ethanal contents, as the primary volatile compounds within the fermented samples, was carried out using standards based on deuterium in place of hydrogen (tetradeutero-

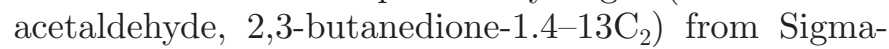
Aldrich (Alonso and Fraga, 2001; Snow and Slack, 2002).

The determination of the lactic acid, ethanol, lactose, and galactose contents of the fermented samples was conducted using an HPLC method. (Indyk et al., 1996; Bylund et al., 2007). To eliminate protein from the tests, thermal acid hydrolysis was carried out. Samples $(0.3 \mathrm{~g})$ were mixed with $0.3 \mathrm{~mL}$ of $0.01 \mathrm{M} \mathrm{H}_{2} \mathrm{SO}_{4}$ (for samples taken after fermentation) or with $0.013 \mathrm{M}$ $\mathrm{H}_{2} \mathrm{SO}_{4}$ (for samples taken before fermentation). The hydrolysis was carried out at $80^{\circ} \mathrm{C}$ for $20 \mathrm{~min}$, after which the samples were processed in a centrifuge for 10 min at $3,500 \times g$ at $25^{\circ} \mathrm{C}$, and the resulting supernatant was filtered using a Millex filter (LCR PTFE $0.45 \mathrm{~nm}$; Millipore Co., Carrigtwohill, Ireland). The filtrate was injected onto an HPX 87H column (BioRad, Hercules, $\mathrm{CA}$ ) combined with a refractive index (RI) detector.
The volume of the injected sample was $20 \mu \mathrm{L}$. The mobile phase consisted of a $5 \mathrm{mM} \mathrm{H}_{2} \mathrm{SO}_{4}$ solution. The analysis period was $30 \mathrm{~min}$ at $30^{\circ} \mathrm{C}$ using a flowrate of $0.6 \mathrm{~mL} / \mathrm{min}$ (Bertelli et al., 1996).

The proportion of $\mathrm{L}(+)$-lactic acid was based on an enzymatic reaction in which $\mathrm{L}(+)$-lactic acid is oxidized to pyruvate by using nicotinamide adenine dinucleotide $\left(\mathrm{NAD}^{+}\right)$and L-lactate dehydrogenase $(\mathbf{L}-\mathbf{L D H})$. The resulting pyruvate was spin tapped using D-glutamic pyruvate transaminase (D-GPT; Gawehn, 1988; Noll, 1988). The experiment used the K-DLATE experimental set produced by Megazyme (Wicklow, Ireland).

A kefir sample $(0.1 \mathrm{~mL})$ to be classified was combined with $0.5 \mathrm{~mL}$ of glycylglycine buffer $(0.5 \mathrm{M}, \mathrm{pH} 10.0)$, $0.1 \mathrm{~mL}$ of $\mathrm{NAD}^{+}$, and $0.02 \mathrm{~mL}$ of D-GPT suspension $(1,300 \mathrm{U} / \mathrm{mL})$. The classification of samples was carried out as follows: $1 \mathrm{~g}$ of kefir was added to a $100-\mathrm{mL}$ volumetric flask containing $60 \mathrm{~mL}$ of distilled water. Next, $2 \mathrm{~mL}$ of Carrez I reagent, $2 \mathrm{~mL}$ of Carrez II reagent, and $4 \mathrm{~mL}$ of $\mathrm{NaOH}$ solution $(100 \mathrm{~m} M)$ were added. The value of $\mathrm{L}(+)$-lactic acid was calculated based on the absorbency difference at a wavelength of $340 \mathrm{~nm}$ before and after adding $0.02 \mathrm{~mL}$ of L-LDH $(2,000 \mathrm{U} / \mathrm{mL})$ to the previously prepared suspended matter.

The $\mathrm{pH}$ value was measured using a CP-411 type Elmetron pH-meter (Zabrze, Poland) equipped with a ESAgP-301W type combined electrode probe (Eurosensor, Gliwice, Poland) consisting of a glass half-cell and a silver chloride half-cell. The measurement was carried out in accordance with the guidelines specified by Martinez-Villaluenga et al. (2006).

Lactase activity was determined using the method proposed by Passerat and Desmaison (1995). The results were given in microkatals per one hundred grams ( $\mu \mathrm{kat} / 100 \mathrm{~g}$ ) of sample. One unit of enzyme was defined as the amount of catalyst that converted $1 \mathrm{~mol}$ of the substrate within $1 \mathrm{~s}$ under the specified reaction conditions.

Sensory evaluation was performed using the profiling method. The panel consisted of a team of 10 people, appropriately trained and prepared for the evaluation. Panelists exhibiting no known illness at the time of examination and with audited olfactory and gustatory function were used. In the preceding weekly training sessions, 10 assessors (4 males, 6 females) were recruited and trained for at least 6 mo to orthonasally and retronasally recognize about a dozen selected odorants at different odorant concentrations. An intensity scale from 1 to 10 points was used, where 1 indicated a barely detectable odor and 10 being a very intense odor (Karagül-Yüceer et al., 2001). The samples were prepared according to Spitzer and Buettner (2010). To visualize olfactory perception, the results were presented in the form of histograms. To enable the placement 
Table 2. Descriptors of fermented samples subjected to sensory examination

\begin{tabular}{lll}
\hline Term & Definition & Benchmark \\
\hline Cooked & Aromatics associated with cooked milk & Milk heated at $85^{\circ} \mathrm{C}$ for $30 \mathrm{~min}$ \\
Whey & Aromatics associated with whey powder & 5 g of whey powder dissolved in $100 \mathrm{~mL}$ of water \\
Creamy & Aromatics associated with milk fat & Cream or butter \\
Cereal & Aromatics associated with breakfast cereals, oats & Oat biscuits \\
Animal & Aromatics associated with barns and livestock & $5 \%$ calcium caseinate solution \\
Cardboard & Aromatics associated with wet cardboard & Cardboard soaked in water \\
Fermented & Aromatics associated with fermented milk & Fresh fermented milk \\
Sour & Taste sensation associated with acids & $2=0.005 \% 5=0.08 \%$ citric acid solution \\
Salty & Taste sensation associated with salts & $2.5=0.2 \%$ NaCl solution \\
Sweet & Taste sensation associated with sugars & $2=2 \%, 5=5 \%$ sucrose solution \\
Astringent & A drying effect on the tongue surface caused by substances such & A bag of tea brewed for $1 \mathrm{~h}$ in a glass $=6.5$ \\
& as tannins & \\
\hline
\end{tabular}

of tested samples in the perception range, the results were evaluated using the principal component analysis method (Stampanoni, 1994). A symmetrical diagonalization of the correlation matrix was performed (Barron et al., 2005). Assessment descriptors with their definitions and benchmarks are included in Table 2 (Drake, 2004; Isleten and Karagul-Yuceer, 2006; Adhikari et al., 2010; Cais-Sokolińska et al., 2011).

The experiment was done on the pilot scale. The frequency and choice of research methods in the described experiment allowed for full characterization of the initial material, analysis of the dynamics of acidification, and assessment of the quality of the resulting kefir, with respect to increased levels of PUFA content. For verification of statistical hypotheses, a level of significance at $\alpha=0.05$ was adopted. The statistical calculations were made using Statistica software (version 10, StatSoft Inc., Tulsa, OK). The correlation coefficient significance tests were based on the assumption of normal distribution of the residual value of the $y$ variable and an equal residual value variation for all values of the $x$ variable. To eliminate deviations from Pearson's distribution linearity, which could cause an increase of the square sum of deviations from the regression line, a scatter diagram analysis was performed. Paired Kolmogorov-Smirnov $t$-tests were used for the calculations and multivariate exploratory techniques. The nonlinear iterative paired least squares (NIPALS) algorithm was used for computing the first few components in a partial least squares analysis.

\section{RESULTS AND DISCUSSION}

The basic chemical composition of milk from both nutritional groups of the tested species (goat and sheep) was similar $(P>0.05$, Table 3$)$. The FA profile of the tested milk is presented in Table 4. Goats receiving dietary supplements in the form of DDGS produced milk with higher contents of CLA and PUFA $(P<$ 0.05) compared with goats in the control group. The content of SFA in milk from DDGS goat group was lower than in the milk from the control group $(P<$ $0.05)$; a lower content of SFA is beneficial for human health. This correlation was not observed in ewe milk, in which the contents of CLA and SFA in both groups were similar $(P>0.05)$. Ewe milk from the DDGS group had a statistically significant higher content of PUFA and unsaturated FA, compared with milk from ewes in the control group.

Fermentation time had a significant effect on the content of 2,3-butanedione in the tested milk samples (Table 5). In the first $10 \mathrm{~h}$ of fermentation, more 2,3-butanedione was produced in ewe milk compared with in goat milk $(P<0.05)$. However, in the finished product, the highest content of 2,3-butanedione $(>4.6 \mu \mathrm{g} / \mathrm{g})$ was found in goat milk with an increased content of PUFA,

Table 3. Basic chemical composition of goat and sheep milk (mean \pm SD) from animals fed forage supplemented with maize dried distillers grains with solubles (DDGS)

\begin{tabular}{|c|c|c|c|c|}
\hline \multirow[b]{2}{*}{ Item $(\%)$} & \multicolumn{2}{|c|}{ Goat milk } & \multicolumn{2}{|c|}{ Ewe milk } \\
\hline & Control & DDGS & Control & DDGS \\
\hline Fat & $3.38 \pm 0.29$ & $3.34 \pm 0.31$ & $5.28 \pm 0.46$ & $5.21 \pm 0.35$ \\
\hline Protein & $3.45 \pm 0.26$ & $3.42 \pm 0.22$ & $4.08 \pm 0.32$ & $4.12 \pm 0.29$ \\
\hline Lactose & $4.61 \pm 0.13$ & $4.63 \pm 0.11$ & $4.98 \pm 0.14$ & $4.91 \pm 0.11$ \\
\hline DM & $12.41 \pm 0.64$ & $12.37 \pm 0.61$ & $16.08 \pm 0.72$ & $16.12 \pm 0.69$ \\
\hline
\end{tabular}


Table 4. Fatty acid profiles of goat and ewe milk (g/100 g of total FA, mean $\pm \mathrm{SD}$ ) from animals fed forage supplemented with maize dried distillers grains with solubles (DDGS)

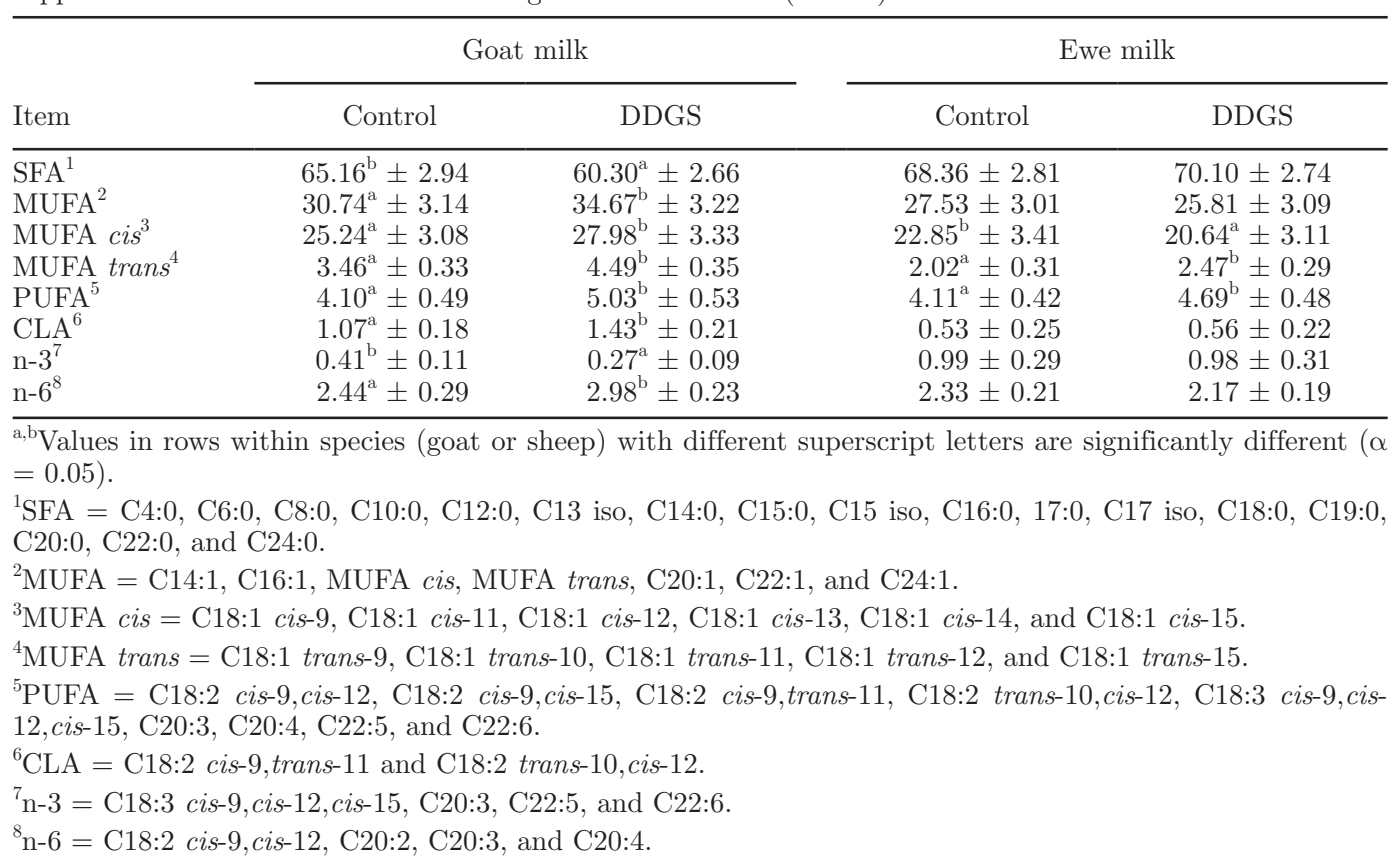

resulting from the DDGS-supplemented forage. This amount exceeded the content of 2,3-butanedione in ewe milk kefir by $1.452 \mu \mathrm{g} / \mathrm{g}$ (the DDGS group), regardless of the feeding method $(P<0.05)$.

The content of 2,3-butanedione (or diacetyl) in the tested samples was most likely influenced by the activity of pyruvic dehydrogenase and the presence of magnesium and manganese ions, which cause the decarboxylation of pyruvic acid to 2,3-butanedione. Dehydrogenase exhibits increased activity in the presence of increased levels of lipoic acid in the substrate. Lipoic acid is one of the coenzymes in the multi-enzyme compounds of $\alpha$-keto-acid dehydrogenase, such as pyruvate dehydrogenase, 2-oxoglutarate dehydrogenase, and $\alpha$-keto-acid dehydrogenase with branching chains and in a glycine-dispersing compound (Malińska and Winiarska, 2005).
The content of 2,3-butanedione determined by Beshkova et al. (2003) in different experimental samples of milk fermented by mesophilic kefir cultures was between 1.00 and $1.85 \mu \mathrm{g} / \mathrm{g}$. In commercially available beverages with thermophilic LAB, the average content of 2,3-butanedione determined by Alonso and Fraga (2001) was $11.36 \mathrm{mg} / \mathrm{g}$. The extended time of fermentation in the fermented milk could contribute to the dissipation of the 2,3-butanedione aroma as a result of reducing the 2,3-butanedione through the addition of acetoin reductase. This is an irreversible reaction when lactose fermentation bacteria are used.

Among the analyzed samples, more ethanal was identified in fermented ewe milk than in goat milk, regardless of fermentation time (Table 6). Treatment group in ewes significantly affected content of ethanal in milk $(P<0.05)$. Kefir made from ewe milk with an

Table 5. Changes in 2,3-butanedione $(\mu \mathrm{g} / \mathrm{g}$, mean $\pm \mathrm{SD})$ content during lactose-alcohol fermentation $(\mathrm{df}=9)$ in goat and ewe milk from animals fed forage supplemented with maize dried distillers grains with solubles (DDGS)

\begin{tabular}{|c|c|c|c|c|}
\hline Sample type & \multicolumn{2}{|c|}{ Goat milk } & \multicolumn{2}{|c|}{ Ewe milk } \\
\hline $\begin{array}{l}\text { Unfermented milk } \\
\text { Fermentation }\end{array}$ & $0.095^{\mathrm{a}, \mathrm{A}} \pm 0.012$ & $0.035^{\mathrm{a}, \mathrm{A}} \pm 0.009$ & $0.106^{\mathrm{a}, \mathrm{A}} \pm 0.023$ & $0.037^{\mathrm{a}, \mathrm{A}} \pm 0.006$ \\
\hline $\begin{array}{l}\text { Fermentation } \\
5 \mathrm{~h}\end{array}$ & $1.229^{\mathrm{a}, \mathrm{B}} \pm 0.045$ & $1.156^{\mathrm{a}, \mathrm{B}} \pm 0.078$ & $1.783^{\mathrm{b}, \mathrm{B}} \pm 0.021$ & $1.514^{\mathrm{b}, \mathrm{B}}+0.034$ \\
\hline $10 \mathrm{~h}$ & $1.874^{\mathrm{a}, \mathrm{B}} \pm 0.057$ & $1.730^{\mathrm{a}, \mathrm{B}} \pm 0.012$ & $2.945^{\mathrm{b}, \mathrm{C}} \pm 0.280$ & $2.871^{\mathrm{b}, \mathrm{C}} \pm 0.540$ \\
\hline $15 \mathrm{~h}$ & $3.619^{\mathrm{b}, \mathrm{C}} \pm 0.412$ & $3.509^{\mathrm{b}, \mathrm{C}} \pm 0.327$ & $3.046^{\mathrm{a}, \mathrm{C}} \pm 0.460$ & $3.102^{\mathrm{a}, \mathrm{C}} \pm 0.743$ \\
\hline
\end{tabular}

$\overline{\mathrm{a}-\mathrm{c}, \mathrm{A}-\mathrm{D}}$ Values in rows with different lowercase letters and in columns with different uppercase letters are significantly different $(\alpha=0.05)$. 
Table 6. Changes in the content of ethanal ( $\mu \mathrm{g}$ per g, mean $\pm \mathrm{SD}$ ) content during lactose-alcohol fermentation $(\mathrm{df}=9)$ in goat and ewe milk from animals fed forage supplemented with maize dried distillers grains with solubles (DDGS)

\begin{tabular}{|c|c|c|c|c|}
\hline \multirow[b]{2}{*}{ Sample type } & \multicolumn{2}{|c|}{ Goat milk } & \multicolumn{2}{|c|}{ Ewe milk } \\
\hline & Control & DDGS & Control & DDGS \\
\hline $5 \mathrm{~h}$ & $0.598^{\mathrm{a}, \mathrm{A}} \pm 0.052$ & $0.677^{\mathrm{a}, \mathrm{B}} \pm 0.031$ & $1.455^{\mathrm{b}, \mathrm{B}} \pm 0.055$ & $1.306^{\mathrm{b}, \mathrm{B}} \pm 0.077$ \\
\hline $10 \mathrm{~h}$ & $2.503^{\mathrm{a}, \mathrm{B}} \pm 0.412$ & $2.114^{\mathrm{a}, \mathrm{C}} \pm 0.083$ & $4.485^{\mathrm{b}, \mathrm{C}} \pm 0.998$ & $4.637^{\mathrm{b}, \mathrm{C}} \pm 0.255$ \\
\hline $15 \mathrm{~h}$ & $4.887^{\mathrm{a}, \mathrm{C}} \pm 0.560$ & $5.409^{\mathrm{a}, \mathrm{D}} \pm 0.773$ & $6.449^{\mathrm{b}, \mathrm{D}} \pm 1.117$ & $8.413^{\mathrm{c}, \mathrm{D}} \pm 0.988$ \\
\hline
\end{tabular}

$\overline{\mathrm{a}-\mathrm{c}, \mathrm{A}-\mathrm{E}}$ Values in rows with different lowercase letters and in columns with different uppercase letters are significantly different $(\alpha=0.05)$.

increased content of PUFA (i.e., the DDGS group) had $12 \%$ more ethanal compared with that from the control group $(P<0.05)$. Ethanal content was $44 \%$ higher (at $4.161 \mu \mathrm{g} / \mathrm{g})$ than that determined in goat milk kefir $(P$ $<0.05)$.

The basic distinguishing factor in the assessment of fermented products incorporating bacteria and yeast is the content of lactic acid and ethanol. Based on the tests conducted, we determined that, regardless of fermentation time, more lactic acid was produced in ewe milk compared with goat milk (Table 7). The highest content of acid was seen in ewe milk kefir, independent of treatment group (PUFA concentration). Over half of the content of lactic acid in the finished product was generated in the first and second incubation phases (between 5 and $10 \mathrm{~h}$ ) of the processed milk. No statistically significant differences in lactic acid content were determined in samples incubated for $15 \mathrm{~h}$ or in the finished product, regardless of the milk type or experimental group from which the milk was acquired. The differing content of PUFA in the raw milk from both feeding groups did not have an effect on the share of $\mathrm{L}(+)$-lactic acid formed in kefirs from either type of milk. On average, in goat milk kefirs, this share was $89.2 \%$ of total lactic acid content and was significantly lower $(P<0.05)$ in ewe milk kefirs, at $77.4 \%$.
Neither the type of milk nor the treatment group had a statistically significant effect on ethanol content in the fermented samples. After $5 \mathrm{~h}$ of fermentation, the average ethanol content in the tested samples was $0.10 \%$, and in subsequent hours reached $0.40 \%$. An average of $0.49 \%$ ethanol content was observed in kefirs as a whole.

The fermentation process of selected types of milk and their mixtures contributed to an increased galactose content as a result of lactose decomposition (Figure 1). An analysis of the correlation between lactose and galactose contents in goat and ewe milk samples with varying contents of PUFA showed, according to the Guilford scale, a very high correlation of $r>0.97$. In goat milk kefir, the galactose content averaged 0.22 $\mathrm{g} / \mathrm{L}$, and this was significantly higher in ewe milk $(0.31$ $\mathrm{g} / \mathrm{L}, P<0.001)$. Goat milk from both nutritional groups was characterized by the same galactose content trend, which was also observed in the second fermentation phase for ewe milk. On the other hand, lactose content determined after $5 \mathrm{~h}$ of fermentation was significantly higher in milk from control group ewes $(P<0.001)$. Based on the degree of lactose hydrolysis, goat milk was characterized by a higher fermentation process dynamic compared with ewe milk, which is evidenced by a higher linear alignment of the directional coefficient

Table 7. Changes to the content of lactic acid $(\mathrm{g} / \mathrm{L}$, mean $\pm \mathrm{SD})$ during lactose-alcohol fermentation $(\mathrm{df}=$ 9 ) in goat and ewe milk from animals fed forage supplemented with maize dried distillers grains with solubles (DDGS)

\begin{tabular}{|c|c|c|c|c|}
\hline \multirow[b]{2}{*}{ Sample type } & \multicolumn{2}{|c|}{ Goat milk } & \multicolumn{2}{|c|}{ Ewe milk } \\
\hline & Control & DDGS & Control & DDGS \\
\hline Unfermented milk & $\mathrm{ND}^{1}$ & ND & ND & ND \\
\hline \multicolumn{5}{|l|}{ Fermentation } \\
\hline $5 \mathrm{~h}$ & $4.38^{\mathrm{cA}} \pm 1.12$ & $4.26^{\mathrm{cA}} \pm 0.26$ & $3.17^{\mathrm{aA}} \pm 0.14$ & $3.69^{\mathrm{bA}} \pm 0.07$ \\
\hline $10 \mathrm{~h}$ & $5.89^{\mathrm{aB}} \pm 0.89$ & $5.74^{\mathrm{aB}} \pm 0.58$ & $6.14^{\mathrm{aB}} \pm 0.04$ & $7.03^{\mathrm{bB}} \pm 0.11$ \\
\hline $15 \mathrm{~h}$ & $6.81^{\mathrm{aC}} \pm 0.25$ & $6.97^{\mathrm{aC}} \pm 1.13$ & $8.56^{\mathrm{bC}} \pm 0.27$ & $8.61^{\mathrm{bC}} \pm 0.74$ \\
\hline Kefir & $7.09^{\mathrm{aC}} \pm 1.13$ & $7.20^{\mathrm{aC}} \pm 0.98$ & $9.11^{\mathrm{bC}} \pm 0.46$ & $9.07^{\mathrm{bC}} \pm 0.10$ \\
\hline
\end{tabular}




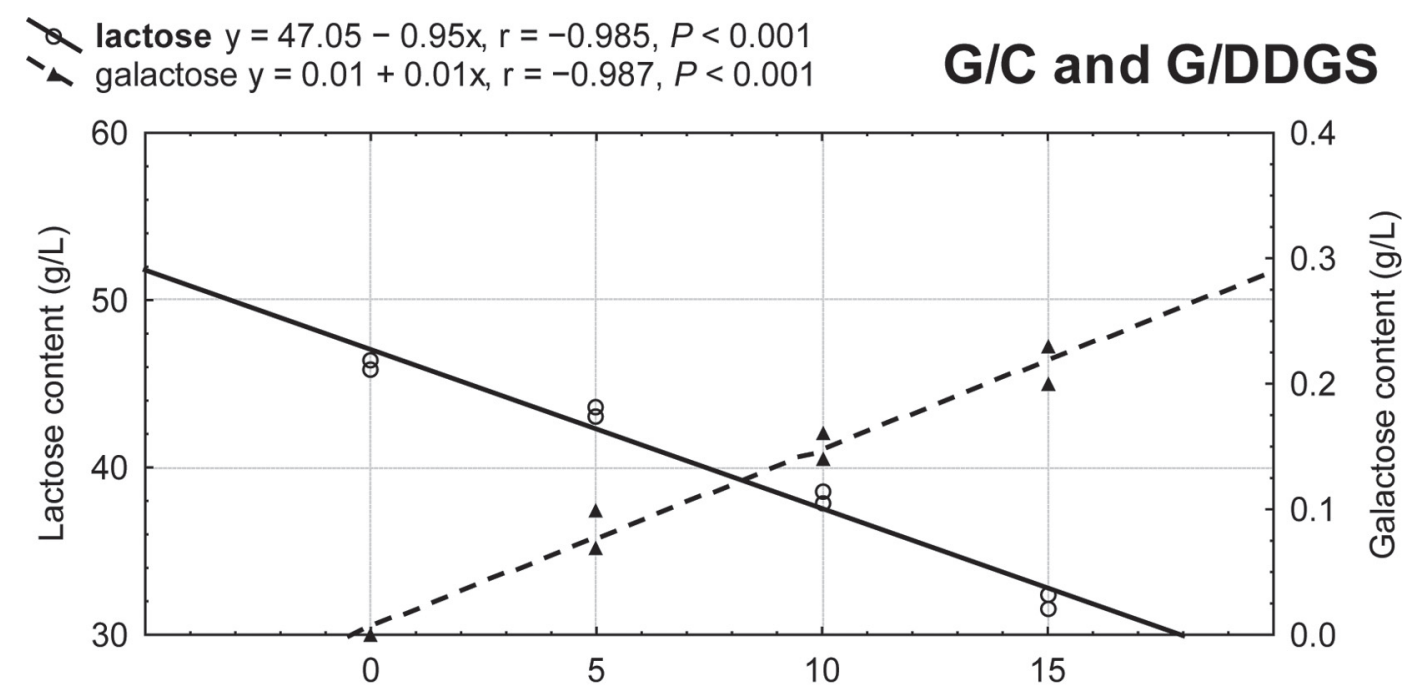

Lactose $y=59.65-1.62 x, r=-0.976, P<0.001$
2 galactose $y=0.02+0.02 x, r=-0.969, P<0.001 \quad$ E/C and E/DDGS

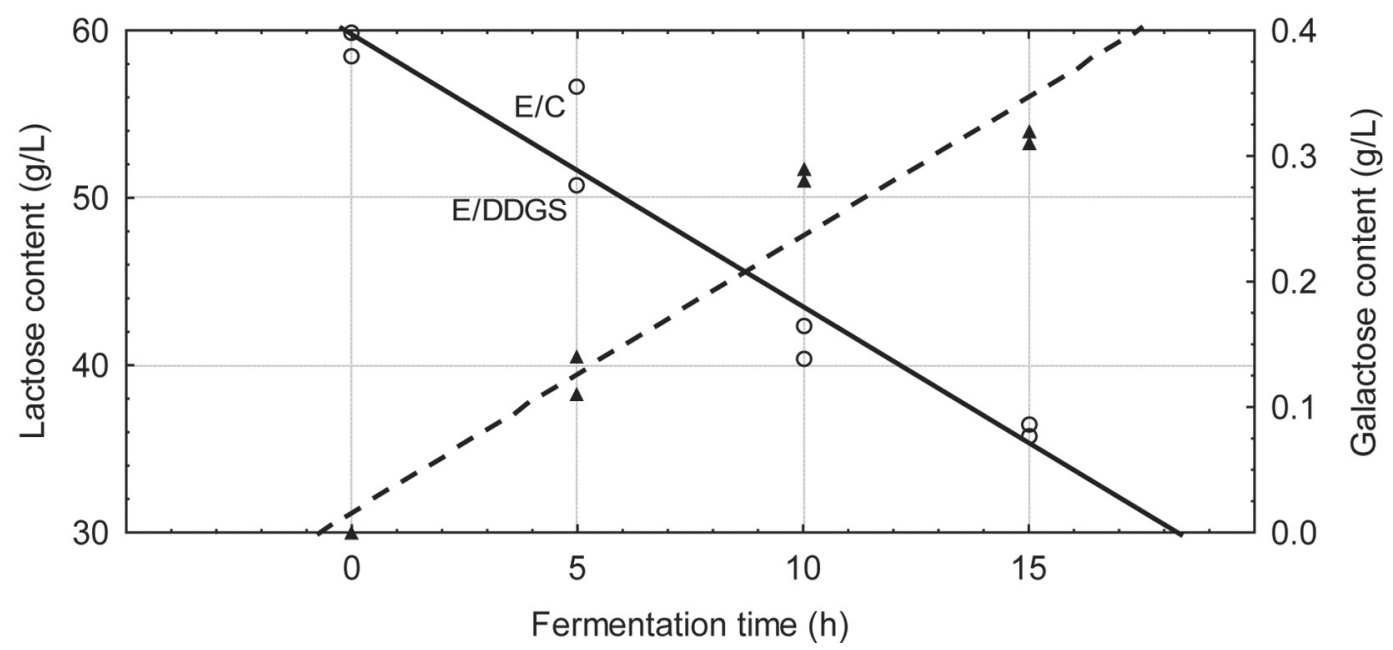

Figure 1. Lactose $(\mathrm{g} / \mathrm{L})$ and galactose $(\mathrm{g} / \mathrm{L})$ content change dynamics in goat and ewe milk during lactose-alcohol fermentation $(\mathrm{df}=11)$. $\mathrm{G}=$ goat; $\mathrm{E}=$ ewe; $\mathrm{C}=$ control milk; DDGS = goat and ewe milk from animals fed forage supplemented with maize dried distillers grains with solubles.

function $(|\mathrm{a}|=1.62)$. During goat milk fermentation, regardless of the content of PUFA, a hydrolysis level of $32 \%$ was recorded. In comparison, for ewe milk, $39 \%$ of the initial lactose amount was subject to hydrolysis. No statistically significant lactose content differences were determined in the samples of milk fermented for $15 \mathrm{~h}$ and in the finished product. The correlation applied to all milk samples that were analyzed.

Small quantities of ethane in the fermented milk could be the result of high levels of free glycine (Aghlara et al., 2009). Glycine has an inhibiting effect on threonine aldolase, which converts threonine into ethanal. Additionally, the small quantity of ethanal generated in fer- mented milk may be a result of a smaller yeast content (Alvarez-Martin et al., 2008). Yeasts contribute to the synthesis of ethanal through the direct decarboxylation of pyruvic acid, whereas lactose fermentation bacteria do not have pyruvic decarboxylase and synthesize ethanal from acetyl-CoA, acetyl phosphates, and acetates. This metabolic pathway is characterized by a higher ethanal synthesis dynamic (Aghlara et al., 2009). A higher concentration of maltic compounds in the presence of yeasts and LAB indicates enhanced reduction of aldehydes to alcohols. This is because ethanal is used by the LAB strains present in fermented samples, which constitutes an inoculum, such as Lactococcus lactis ssp. 
lactis, Lactococcus lactis ssp. cremoris, as well as Leuconostoc mesenteroides ssp. cremoris. Güzel-Seydim et al. (2000) stated that, during the production of kefir from bovine milk, it took $10 \mathrm{~h}$ of fermentation at $25^{\circ} \mathrm{C}$ to achieve a noticeable accumulation of ethanal. However, between 15 and $22 \mathrm{~h}$ of incubation, the amount of ethanal increased significantly from 11 to $26 \mu \mathrm{g} / \mathrm{g}$ in that study. Determining the ethanal content in kefirs stored up to $7 \mathrm{~d}$ in cold storage, Beshkova et al. (2003) showed that these had quantities between 5.6 and 18.1 $\mu \mathrm{g} / \mathrm{g}$. In comparison, in milk fermented with thermophilic bacteria (e.g., yogurts), the content of ethanal is $5.18 \mathrm{mg} / \mathrm{kg}$ (Alonso and Fraga, 2001). Sahan et al. (2008), on the other hand, determined ethanal content from $10.6 \mathrm{mg} / \mathrm{kg}$ (on d 1 of storage) to $7.0 \mathrm{mg} / \mathrm{kg}$ (on d 15 of storage). The use of thermophilic bacteria of the Lactobacillus and Streptococcus type, in a proportion of $10 \mathrm{~g}$ of yeast per $\mathrm{kg}$ containing 7 to $9 \mathrm{log} \mathrm{cfu} / \mathrm{g}$, for the production of a beverage from mixed ewe and mare milk, contributed to the synthesis of $0.25 \mathrm{mM}$ ethanal (Cagno et al., 2004). After 45 d of storage, those authors measured more ethanol in the fermented mixture than at the start of the storage period $(0.28 \mathrm{mM})$.

The active acidity of milk before the fermentation process was within a $\mathrm{pH}$ range from 6.50 to 6.61 . The fermentation process contributed to a significant reduction of $\mathrm{pH}$ below the assumed value of $\mathrm{pH}$ 4.4. The significance test that compared distribution functions of observed samples and those originating from the Kolmogorov-Smirnov simulation made it possible to assess the dynamic of lactic acid fermentation of samples and to determine an average value for unimodal distribution (value M, Figure 2). On this basis, we concluded that the slowest fermentation process was initiated for ewe milk originating from the control group, where after $5 \mathrm{~h}$ of incubation the milk had the same $\mathrm{pH}$ value as before fermentation. Additionally, control ewe milk displayed the least predictable fermentation dynamic out of all the samples analyzed (test value $x^{2}=34.126$ ).

The regulation of fermentation dynamics based on $\mathrm{pH}$ values in the milk of ewes fed DDGS was characterized by a decrease in the observed variation value $(\mathrm{W}$ $=0.932$, Figure 2 ) by almost $17.5 \%$. We also showed that the differing contents of PUFA in control and experimental goat milk had no effect on the fermentation process or $\mathrm{pH}$ value of produced kefirs. In goat milk from both groups, significant $\mathrm{pH}$ changes were observed in the initial fermentation period. The rapid decrease in $\mathrm{pH}$ values of those goat milk samples, compared with ewe milk, was most likely due to the lower buffer level and higher content of nonprotein nitrogen.

Subsequent hours of goat milk fermentation significantly affected lactase activity, regardless of the con- tent of PUFA (Table 8). On the other hand, the final fermentation phase of sheep milk fermentation did not contribute to a change in lactase activity. After $15 \mathrm{~h}$ of fermentation, fermented goat milk with an increased content of PUFA was characterized by a significantly higher lactase activity. The activity of lactase in the resulting kefirs was between $0.29 \mu \mathrm{kat} / 100 \mathrm{~g}$ (in ewe milk kefirs, regardless of treatment group) and 0.49 $\mu \mathrm{kat} / 100 \mathrm{~g}$ (in goat milk kefir, with an increased content of PUFA).

By analyzing the sensory assessment descriptors of the kefir's aroma and flavor, we showed that whey, animal, and cream aromas had a decisive influence on their diversity of perception (Figure 3 ). The whey aroma was most noticeable in samples of fermented goat milk (6.7 points in kefir from the control group and 4.8 points in kefir from the experimental group goat milk). The whey aroma was least noticeable in ewe milk kefir, at 1.4 (control) and 2.0 points (experimental group), respectively. Animal odor was most noticeable in kefir produced from goat milk, regardless of the content of PUFA, and scored an average of 7.2 points. In kefir produced from ewe milk, as the content of PUFA increased (DDGS group), the animal odor decreased, from 6.6 to 4.4 points. Simultaneously, in the same samples of ewe milk kefir, there was an intensification of a cream aroma, from 3.8 points (control) to 4.2 points (experimental group, with an increased PUFA content). The cream aroma was not detected at all in goat milk kefirs (1 point). Regardless of the type of milk and its content of PUFA, the resulting kefirs did not show any salty or astringent taste. Sweet taste was more noticeable in kefirs from ewe milk compared with goat milk (2.1 points). Ewe milk kefirs from both nutritional groups were more sour (2.7 points) compared with goat milk (4.4 points).

In general, all the variables included in the analysis were reduced to a single dimension, because the first primary axis had the largest significance in the explanation of the general volatility of data in the analysis (96.51\%). The principal component (PC) 1 axis explained more than $70 \%$ of the total variation of variables. This allowed us to confirm the differing tastearoma profile of kefir samples produced from goat and ewe milks, regardless of PUFA content, and a similar effect of CLA on the sensory profile of kefirs within each milk type. A correlation matrix was used to build a circle of units indicating the correlative character of the data (Figure 4). All variables were correctly represented by points in the 2-dimensional arrangement of primary axes. The quality of category representation equaled 1 in the case of goat milk kefirs and nearly 1 for ewes milk kefirs with varying contents of PUFA. 
Kolmogorov-Smirnov test $d=0.204$

Chi-square $=21.140, \mathrm{df}=11, P=0.032$

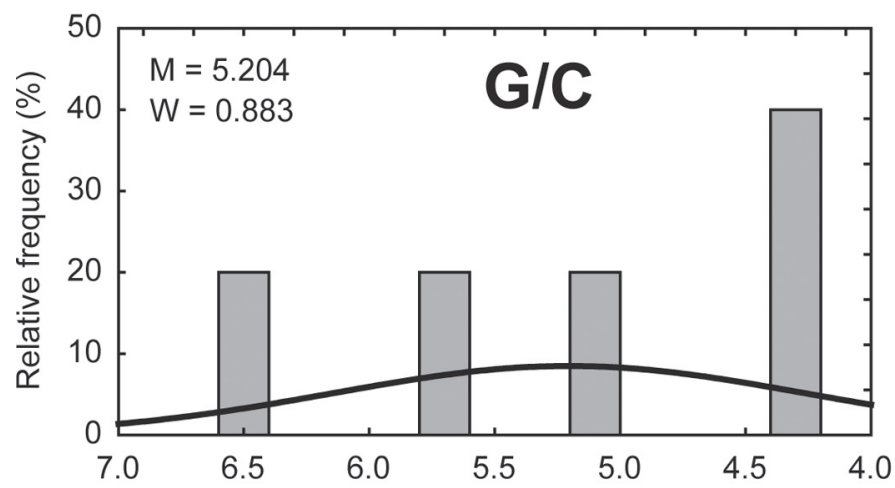

Kolmogorov-Smirnov test $d=0.233$

Chi-square $=34.126, \mathrm{df}=12, P=0.001$

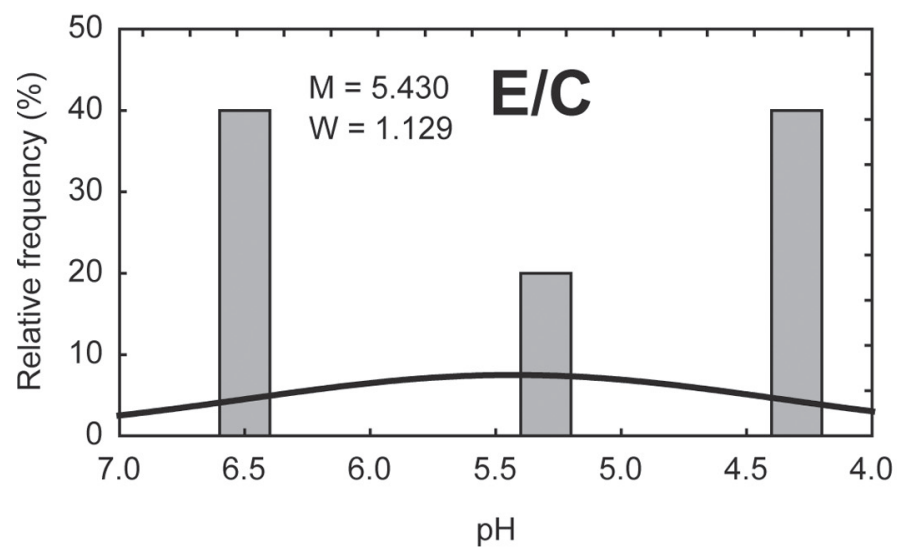

Kolmogorov-Smirnov test $d=0.199$

Chi-square $=21.036, \mathrm{df}=11, P=0.033$

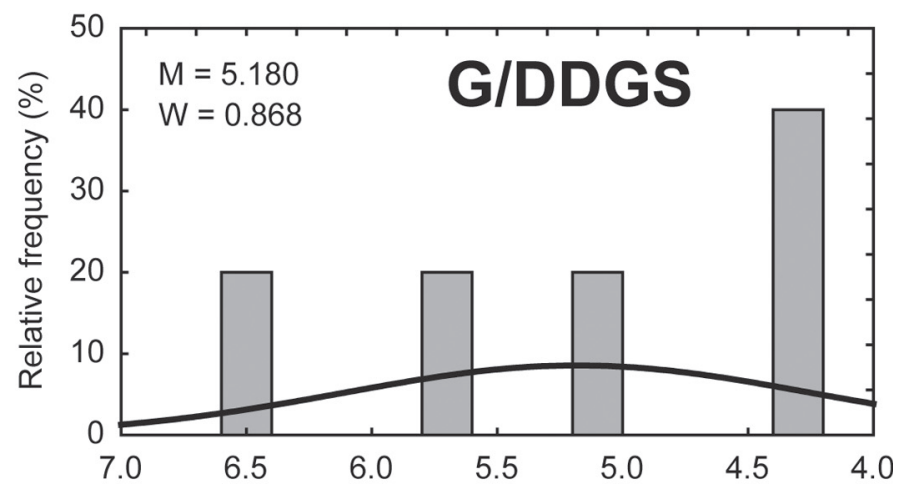

Kolmogorov-Smirnov test $\mathrm{d}=0.176$

Chi-Square $=18.951, \mathrm{df}=10, P=0.041$

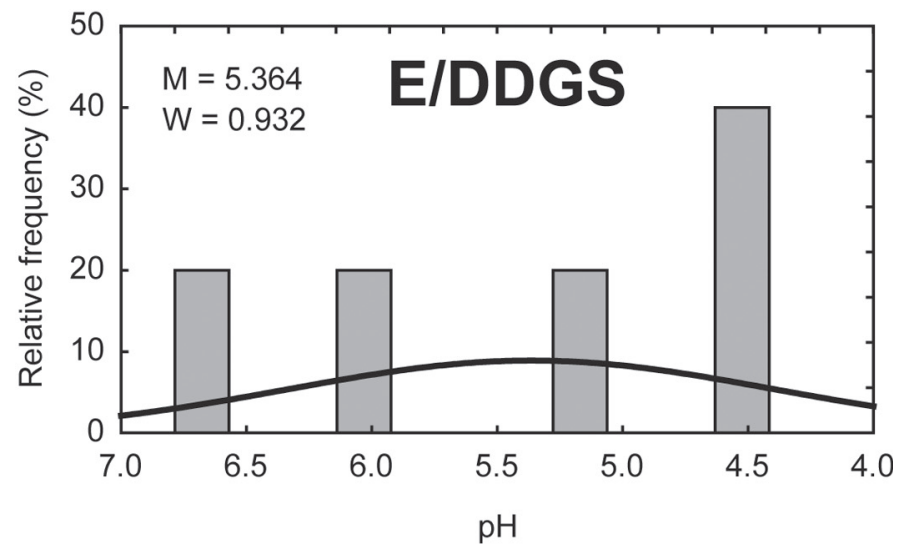

Figure 2. Analysis of the goat and ewe milk fermentation dynamics, based on testing the statistics of achieved active acidity values. $\mathrm{G}=$ goat; $\mathrm{E}=$ ewe; $\mathrm{C}=$ control milk; DDGS = goat and ewe milk from animals fed forage supplemented with maize dried distillers grains with solubles; $\mathrm{M}=$ fit of the observed distribution; $\mathrm{W}=$ estimation of variation.

Table 8. Changes in lactase activity ( $\mu$ kat per $100 \mathrm{~g}$, mean $\pm \mathrm{SD}$ ) during lactose-alcohol fermentation $(\mathrm{df}=$ 9 ) in goat and ewe milk from animals fed forage supplemented with maize dried distillers grains with solubles (DDGS)

\begin{tabular}{|c|c|c|c|c|}
\hline \multirow[b]{2}{*}{ Sample type } & \multicolumn{2}{|c|}{ Goat milk } & \multicolumn{2}{|c|}{ Ewe milk } \\
\hline & Control & DDGS & Control & DDGS \\
\hline Unfermented milk & $\mathrm{ND}^{1}$ & ND & ND & ND \\
\hline Fermentation & & & & \\
\hline $5 \mathrm{~h}$ & $0.07^{\mathrm{a}, \mathrm{A}} \pm 0.03$ & $0.10^{\mathrm{a}, \mathrm{A}} \pm 0.01$ & $0.10^{\mathrm{a}, \mathrm{A}} \pm 0.02$ & $0.11^{\mathrm{a}, \mathrm{A}} \pm 0.02$ \\
\hline $10 \mathrm{~h}$ & $0.18^{\mathrm{a}, \mathrm{B}} \pm 0.01$ & $0.20^{\mathrm{a}, \mathrm{B}} \pm 0.04$ & $0.21^{\mathrm{a}, \mathrm{B}} \pm 0.05$ & $0.20^{\mathrm{a}, \mathrm{B}} \pm 0.02$ \\
\hline $15 \mathrm{~h}$ & $0.26^{\mathrm{a}, \mathrm{C}} \pm 0.07$ & $0.37^{\mathrm{b}, \mathrm{C}} \pm 0.11$ & $0.24^{\mathrm{a}, \mathrm{B}} \pm 0.06$ & $0.26^{\mathrm{a}, \mathrm{B}} \pm 0.03$ \\
\hline Kefir & $0.40^{\mathrm{b}, \mathrm{D}} \pm 0.02$ & $0.49^{\mathrm{c}, \mathrm{D}} \pm 0.07$ & $0.30^{\mathrm{a}, \mathrm{B}} \pm 0.02$ & $0.27^{\mathrm{a}, \mathrm{B}} \pm 0.07$ \\
\hline
\end{tabular}

$\overline{\mathrm{a}-\mathrm{c}, \mathrm{A}-\mathrm{D} \text { Values in rows with different lowercase letters and in columns with different uppercase letters are sig- }}$ nificantly different $(\alpha=0.05)$.

${ }^{1}$ Not determined. 


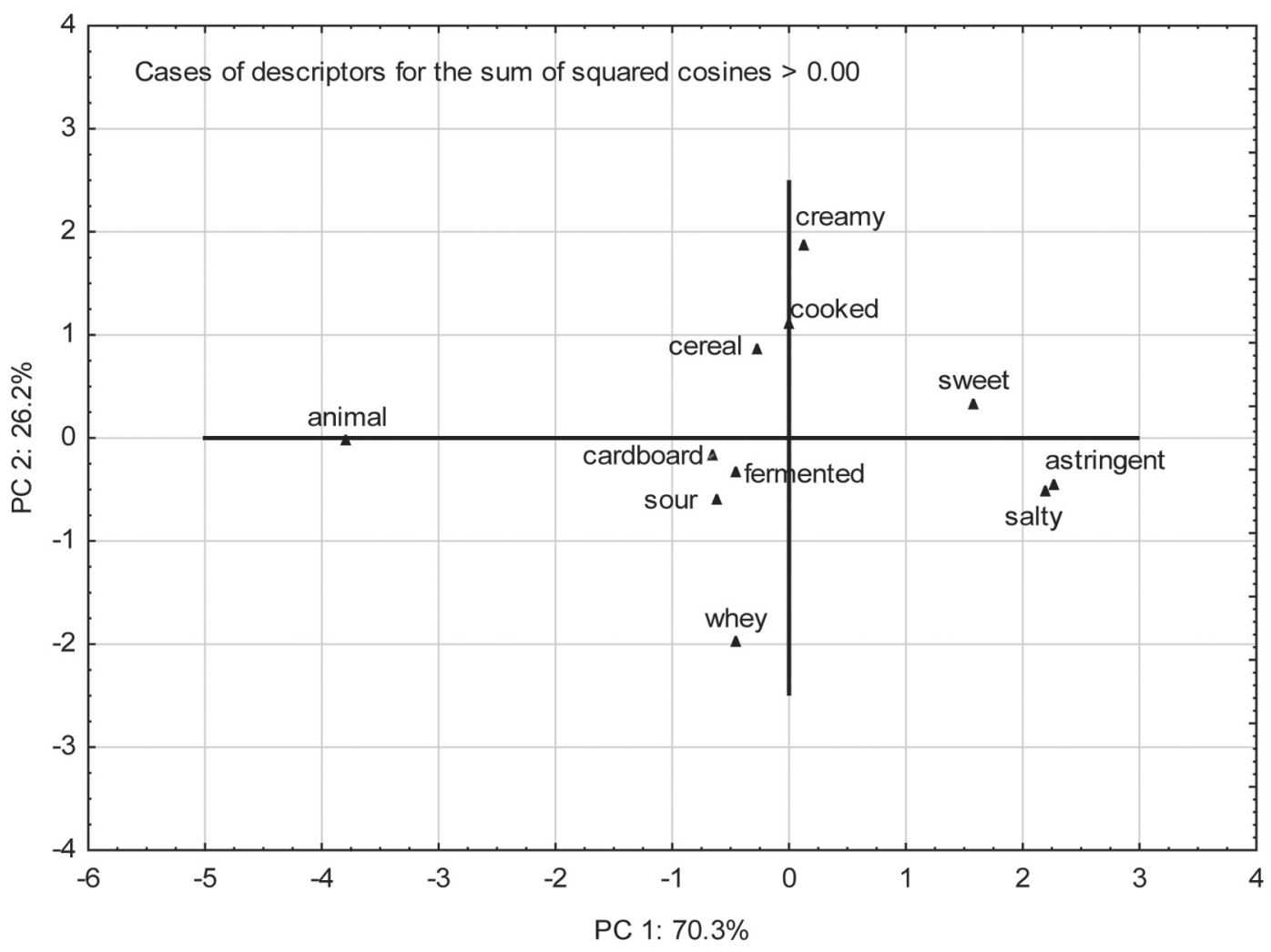

Figure 3. Projection of aroma descriptors of kefirs produced from the experimental goat and ewe milk (from animals fed forage supplemented with maize dried distillers grains with solubles). $\mathrm{PC}=$ principal component.

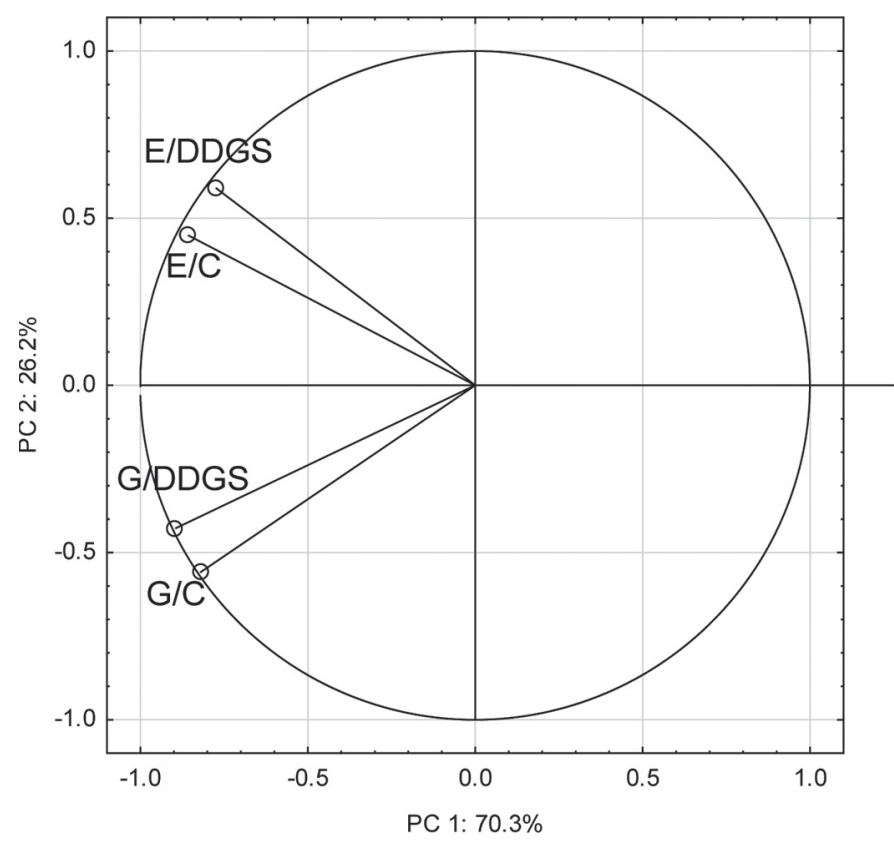

Figure 4. Normalized analysis biplot of the primary components $(\mathrm{PC})$ of the kefir aromas produced from goat $(\mathrm{G})$ and ewe $(\mathrm{E})$ milk. $\mathrm{C}$ $=$ control milk; DDGS $=$ goat and ewe milk from animals fed forage supplemented with maize dried distillers grains with solubles.
The rate and scope of lactose utilization by individual strains of acidifying LAB microflora has been well documented in numerous studies (Oliveira et al., 2001; Meroth et al., 2003). The conducted models of physiological and genetic studies have made it possible to become thoroughly familiar with the microflora that induces milk fermentation (Angulo et al., 1993; Rea et al., 1996). A close correlation has been shown between the number of LAB and the synthesis of lactic acid; however, due to stress and other unspecified factors, the maintenance of lactic acid synthesis by nonviable LAB cells can also occur (van de Guchte et al., 2002). Simultaneously, the participation of yeasts in the synthesis of lactic acid depends on the degree to which they are able to utilize proteins, fat, lactose, and citrate. Some authors (e.g., Alvarez-Martin et al., 2008) have connected the growth of yeasts in dairy products not with their ability to use lactose, but with their ability to metabolize lactic acid. The results of studies into the degree of lactose attenuation in bovine milk with a kefir microflora were described by Irigoyen et al. (2005). According to those authors, after $14 \mathrm{~d}$, the lactose content in the product decreased from 3.51 to $3.20 \%$ with a $1 \%$ inoculum and from 3.41 to $2.94 \%$ with a $5 \%$ inoculum. This shows a lesser degree of at- 
tenuation than that occurring during fermented milk production. In the opinion of Irigoyen et al. (2005), during $24 \mathrm{~h}$ of fermentation, the content of lactose was reduced by 20 to $25 \%$.

Based on several studies, the presence of lactic acid in products has shown additional properties consistent with those of a functional food. This benefit, however, is found mainly in the $\mathrm{L}(+)$ isomeric form of the acid rather than its $\mathrm{D}(-)$ form (Oh et al., 2005; Rojan et al., 2006). The $\mathrm{L}(+)$ form is the sarcomere form, which is completely absorbed by the body as an energy source. The $\mathrm{D}(-)$ form of lactic acid is expelled from the body and, in excess, can lead to acidosis and mineral salts. The form of lactic acid depends on the stereospecificity of lactate dehydrogenase. The $\mathrm{L}(+)$ form of lactic acid is synthesized in the initial stage of milk fermentation, whereas the $\mathrm{D}(-)$ forms in the later stage, and when the fermentation temperature is too high. The lactose fermentation process can facilitate the synthesis of the $\mathrm{D}(-)$ form of lactic acid at levels of between 2 and $>80 \%$.

The amount of accumulated ethanol in the fermented samples is a result of the breakdown of lactose, FA, and AA (Zajšek and Goršek, 2010). A decrease in the contents of ethanal and 2,3-butanedione with a simultaneous increase in the share of ethanol in the fermented milk was described by Georgala et al. (1995). Furthermore, in regard to the influence of temperature on fermentation temperature, the experimental data on ethanol concentration showed that at the end of lag phase, yeasts produced similar amounts of ethanol at 15 and $17^{\circ} \mathrm{C}$, whereas the ethanol level was found to be higher within the range between 19 and $31^{\circ} \mathrm{C}$. The experimental data showed that ethanol concentration increased sharply from approximately $0.1 \mathrm{~g} / \mathrm{L}$ during the lag phase to $7.2,7.6,8.9,10.2$, and $10.7 \mathrm{~g} / \mathrm{L}$ at $23,25,27,29$, and $31^{\circ} \mathrm{C}$, respectively. The highest ethanol concentration was observed at $31^{\circ} \mathrm{C}(10.7 \mathrm{~g} / \mathrm{L})$. Variations in ethanol concentration produced during kefir fermentation could be due to changes in the availability of nutrients and other environmental factors that influence the population of kefir grains yeasts. Güzel-Seydim et al. (2000) showed an ethanol content after only $10 \mathrm{~h}$ of bovine milk incubation inoculated with a kefir microflora. After $15 \mathrm{~h}$ of incubation, it had reached approximately $0.03 \mu \mathrm{g} / \mathrm{L}$. The variation in $\mathrm{pH}$ values of milk subjected to fermentation under the same conditions is a result of differences in the casein and phosphate contents of the processing milk (Egito et al., 2002 The most common kefir produced on an industrial scale has a $\mathrm{pH}$ value between 4.4 and 4.6 , which is usually achieved in a process time of between 16 and $24 \mathrm{~h}$ of fermentation (Wszołek et al., 2001; Ertekin and Güzel-Seydim, 2010).

\section{CONCLUSIONS}

Increasing the level of PUFA in milk fat by supplementation of forage with DDGS contributed to significant changes in the process of the resultant fermentation. This was confirmed by the changes that occurred in the experimental milk during lactose-alcohol fermentation, which qualitatively influenced the properties of the kefirs produced. The highest level of 2,3-butanedione was found in goat milk kefir with an increased content of PUFA. A high level of PUFA in milk fat significantly increased the synthesis of ethanal in ewe milk during the lactose-alcohol fermentation process. The increased content of PUFA helped to equal the rate of sheep milk acidification by increasing the acidification rate in the initial stage of fermentation. The content of PUFA in goat milk had no effect on the acidification process or the $\mathrm{pH}$ value of produced kefirs. An increase in the proportion of PUFA in milk fat influenced the increase in kefir lactase activity only in goat milk kefir. Goat milk kefirs with increased PUFA content had a less prevalent whey aroma. The increased PUFA level eliminated animal odor and resultant in a more prominent cream aroma in ewe milk kefirs.

\section{ACKNOWLEDGMENTS}

This research was conducted under the project "Biofood - innovative, functional animal products" financed by the Polish Ministry of Economy within the European Regional Development Fund 2007-2013, Operating Programme Innovative Economy no. POIG 01.01.02-014-090/09.

\section{REFERENCES}

Adhikari, K., L. M. Dooley, E. Chambers, and N. Bhumiratana. 2010. Sensory characteristics of commercial lactose-free milks manufactured in the United States. Lebenson. Wiss. Technol. 43:113-118.

Aghlara, A., S. Mustafa, Y. A. Manap, and R. Mohamad. 2009. Characterization of headspace volatile flavor compounds formed during kefir production: Application of solid phase microextraction. Int. J. Food Prop. 12:808-818.

Alonso, L., and M. J. Fraga. 2001. Simple and rapid analysis for quantitation of the most important volatile flavor compound in yogurt by headspace gas chromatography-mass spectrometry. J. Chromatogr. Sci. 39:297-300.

Alvarez-Martin, P., A. B. Florez, A. Hernandez-Barranco, and B. Mayo. 2008. Interaction between dairy yeasts and lactic acid bacteria strains during milk fermentation. Food Contr. 19:62-70.

Anderson, J. L., D. J. Schingoethe, K. F. Kalscheur, and A. R. Hippen. 2006. Evaluation of dried and wet distillers grains included at two concentrations in the diets of lactating dairy cows. J. Dairy Sci. 89:3133-3142.

Angulo, L., E. Lopez, and C. Lema. 1993. Microflora present in kefir grains of the Galician region (north-west of Spain). J. Dairy Res. 60:263-267.

AOAC International. 2007. Official Methods of Analysis. 18th ed. AOAC International, Gaithersburg, MD.

Journal of Dairy Science Vol. 98 No. 10, 2015 
Barczak, E., A. Wolc, J. Wójtowski, P. Ślósarz, and T. Szwaczkowski. 2009. Inbreeding and inbreeding depression on body weight in sheep. J. Anim. Feed Sci. 18:42-50.

Barron, L. J. R., Y. Redondo, M. Aramburu, F. J. Pérez-Elortondo, M. Albisu, A. I. Nájera, M. de Renobales, and E. Fernández-Garcia. 2005. Variations in volatile compounds and flavour in Idiazabal cheese manufactured from ewe's milk in farmhouse and factory. J. Sci. Food Agric. 85:1660-1671.

Bendall, J. G. 2001. Aroma compounds of fresh milk from New Zealand cows fed different diets. J. Agric. Food Chem. 49:4825-4832.

Bergamo, P., E. Fedele, L. Iannibelli, and G. Marzillo. 2003. Fat soluble vitamin contents and fatty acid composition in organic and conventional Italian dairy products. Food Chem. 82:625-631.

Bertelli, L., D. Torreggiani, and G. Bertolo. 1996. Non-enzymatic browning in hydrolysed concentrated cheese whey permeate. Food Chem. 55:353-358.

Beshkova, D. M., E. D. Simova, G. I. Frengova, Z. I. Simov, and Z. P. Dimitrov. 2003. Production of volatile aroma compounds by kefir starter cultures. Int. Dairy J. 13:529-535.

Bylund, D., S. H. Norstrom, S. A. Essen, and U. S. Lundstrom. 2007. Analysis of low molecular mass organic acids in natural waters by ion exclusion chromatography tandem mass spectrometry. J. Chromatogr. A 1176:89-93.

Cagno, R., A. Tamborrino, G. Gallo, C. Leone, M. De Angelis, M. Faccia, P. Amirate, and M. Gobetti. 2004. Uses of mare`s milk in manufacture of fermented milks. Int. Dairy J. 14:767-775.

Cais-Sokolińska, D., M. Majcher, J. Pikul, S. Bielińska, M. Czauderna, and J. Wójtowski. 2011. The effect of Camelina sativa cake diet supplementation on sensory and volatile profiles of ewe's milk. Afr. J. Biotechnol. 10:7245-7252

Chilliard, Y., F. Glasser, A. Ferlay, L. Bernard, J. Rouel, and M. Doreau. 2007. Diet, rumen biohydrogenation and nutritional quality of cow and goat milk fat. Eur. J. Lipid Sci. Technol. 109:828855.

Collomb, M., and T. Bühler. 2000. Analyse de la composition en acides gras de la graisse de lait. 1. Optimisation et validation d'une méthode générale à haute resolution. Mitt. Lebensmittel. Hyg. 91:306-332.

Coppa, M., B. Martin, P. Pradel, B. Leotta, A. Priolo, and V. Vasta. 2011. Effect of a hay-based diet or different upland grazing systems on milk volatile compounds. J. Agric. Food Chem. 59:4947-4954.

Couvreur, S., C. Hurtaud, C. Lopez, L. Delaby, and J. L. Peyraud 2006. The linear relationship between the proportion of fresh grass in the cow diet, milk fatty acid composition, and butter properties. J. Dairy Sci. 89:1956-1969.

Dewhurst, R. J., N. D. Scollan, S. J. Youell, J. K. S. Tweed, and M. O. Humphreys. 2001. Influence of species, cutting date and cutting interval on the fatty acid composition of grasses. Grass Forage Sci. $56: 68-74$.

Drake, M. A. 2004. Defining dairy flavor. J. Dairy Sci. 87:777-784.

Duggan, Ch., J. Gannon, and A. Walker. 2002. Protective nutrients and functional foods for the gastrointestinal tract. Am. J. Clin. Nutr. 75:789-808.

Egito, A. S., L. Miclo, C. Lopez, A. Adam, J. M. Girardet, and J. L. Gaillard. 2002. Separation and characterization of mares milk $\alpha_{\mathrm{S1}^{-}}$, $\beta$-, $\kappa$-caseins, $\gamma$-casein-like, and proteose-peptone component 5-like peptides. J. Dairy Sci. 85:697-706.

Ertekin, B., and Z. B. Güzel-Seydim. 2010. Effect of fat replacers on kefir quality. J. Sci. Food Agric. 90:543-548.

Estrada-Angulo, A., E. J. Lopez, G. Contreras, B. J. Castro, J. F. Obregon, and A. B. Perez. 2008. Two levels of dried distillers grains with solubles on growth performances and carcass characteristics of Pelibuey sheep. J Anim Sci. 86(E-Suppl.2):498. (Abstr.)

Gawehn, K. 1988. D-(-)-Lactate. Pages 588-592 in Methods of Enzymatic Analysis. H. U. Bergmeyer, ed. VCH Publishers, Cambridge, UK.

Georgala, A., E. Tsakalidou, I. Kandarakis, and G. Kalantzopoulos. 1995. Flavour production in ewe's milk and ewe's milk yoghurt, by single strains and combinations of Str. salivarius ssp. thermophilus and $L b$. delbrueckii ssp. bulgaricus, isolated from traditional Greek yoghurt. Lait 75:271-283.
Güzel-Seydim, Z. B., A. C. Seydim, A. K. Grenee, and A. B. Bodine. 2000. Determination of organic acids and volatile flavor substances in kefir during fermentation. J. Food Compos. Anal. 13:35-43.

Haenlein, G. F. W. 2004. Goat milk in human nutrition. Small Rumin. Res. 51:155-163.

Helinck, S., D. Le Bars, D. Moreau, and M. Yvom. 2004. Ability of thermophilic lactic acid bacteria to produce aroma compounds from amino acids. Appl. Environ. Microbiol. 70:3855-3861.

Hurtaud, C., L. Delaby, and J.-L. Peyraud. 2007. The nature of preserved forage changes butter organoleptic properties. Lait 87:505519

Indyk, H. E., M. J. Edwards, and D. C. Woollardb. 1996. High performance liquid chromatographic analysis of lactose-hydrolysed milk. Food Chem. 57:575-580.

Irigoyen, A., I. Arana, M. Castiella, P. Torre, and F. C. Ibanez. 2005. Microbiological, physicochemical and sensory characteristics of kefir during storage. Food Chem. 90:613-620

Isleten, M., and Y. Karagul-Yuceer. 2006. Effects of dried dairy ingredients on physical and sensory properties of nonfat yogurt. J. Dairy Sci. 89:2865-2872.

Janicek, B. N., P. J. Kononoff, A. M. Gehman, and P. H. Doane. 2008 The effect of feeding dried distiller's grains plus solubles on milk production and excretion of urinary purine derivatives. J. Dairy Sci. 91:3544-3553.

Karagül-Yüceer, Y., M. A. Drake, and K. R. Cadwallader. 2001. Aroma-active components of nonfat dry milk. J. Agric. Food Chem. 49:2948-2953

Kim, Y. J., R. H. Liu, J. L. Rychlik, and J. B. Russell. 2002. The enrichment of a ruminal bacterium (Megasphaera elsdenii YJ-4) that produces the trans-10, cis-12 isomer of conjugated linoleic acid. J. Appl. Microbiol. 92:976-982.

Kleinschmit, D. H., D. J. Schingoethe, A. R. Hippen, and K. F. Kalscheur. 2007. Dried distillers grains plus solubles with corn silage or alfalfa hay as the primary forage source in dairy cow diets. J. Dairy Sci. 90:5587-5599.

Malińska, D., and K. Winiarska. 2005. Lipoic acid: Characteristics and therapeutic application. Postepy Hig. Med. Dosw. 59:525-543. ]in Polish, with English summary]

Martinez-Villaluenga, C., J. Frias, R. Gomez, and C. Vidal-Valverde. 2006. Influence of addition of raffinose family oligosaccharides on probiotic survival in fermented milk during refrigerated storage. Int. Dairy J. 16:768-774.

Meroth, C. B., J. Walter, C. Hertel, M. J. Brandt, and W. Hammes. 2003. Monitoring the bacterial population dynamics in sourdough fermentation processes by using PCR-denaturing gradient gel electrophoresis. Appl. Environ. Microbiol. 69:475-482.

Noll, F. 1988. L-(+)-Lactate. Pages 582-588 in Methods of Enzymatic Analysis. H. U. Bergmeyer, ed. VCH Publishers, Cambridge, UK.

Nursten, H. E. 1997. The flavour of milk and dairy products: I. Milk of different kinds, milk powder, butter and cream. Int. J. Dairy Technol. 50:48-56.

Oh, H., Y. J. Wee, J. S. Yun, S. H. Han, S. Jung, and H. W. Ryu 2005. Lactic acid production from agricultural resources as cheap raw materials. Bioresour. Technol. 96:1492-1498.

Oliveira, M. N., I. Sodini, F. Remeuf, and G. Corrieu. 2001. Effect of milk supplementation and culture composition on acidification, textural properties and microbiological stability of fermented milks containing probiotic bacteria. Int. Dairy J. 11:935-942.

Park, Y. W., M. Juarez, M. Ramos, and G. F. W. Haenlein. 2007. Physico-chemical characteristics of goat and sheep milk. Small Rumin. Res. 68:88-113.

Passerat, B., and A. M. Desmaison. 1995. Lactase activity of Bifidobacterium bifidum. Nutr. Res. 15:1287-1295.

Rea, M. C., T. Lennartsson, P. Dillon, F. D. Drinan, W. I. Reville, M. Heapes, and T. M. Cogan. 1996. Irish kefir-like grains: Their structure, microbial composition, and fermentation kinetics. J. Appl. Bacteriol. 81:83-94.

Rojan, J. P., K. M. Nampoothiri, and A. Pandey. 2006. Simultaneous saccharification and $\mathrm{L}(+)$-lactic acid fermentation of protease treated wheat bran using mixed culture of lactobacilli. Biotechnol. Lett. 28:1823-1826. 
Sahan, N., K. Yasar, and A. A. Hayaloglu. 2008. Physical, chemical and flavor quality of non-fat yogurt as affected by a $\beta$-glucan hydrocolloidal composite during storage. Food Hydrocoll. 22:12911297.

Schauer, C. S., M. M. Stamm, T. D. Maddock, and B. P. Berg. 2008. Feeding of DDGS in lamb rations. Sheep Goat Res. J. 23:15-19.

Snow, N. H., and G. C. Slack. 2002. Head-space analysis in modern gas chromatography. Trends Analyt. Chem. 21:608-617.

Spitzer, J., and A. Buettner. 2010. Characterization of aroma changes in human milk during storage at $-19^{\circ} \mathrm{C}$. Food Chem. 120:240-246.

Stampanoni, C. R. 1994. The use of standardized flavor languages and quantitative flavor profiling technique for flavored dairy products. J. Sens. Stud. 9:383-400.

Szumacher-Strabel, M., A. Cieślak, P. Zmora, E. Pers-Kamczyc, S. Bielińska, M. Stanisz, and J. Wójtowski. 2011. Camelina sativa cake improved unsaturated fatty acids in ewe's milk. J. Sci. Food Agric. 91:2031-2037.

Urbach, G. 1990. Effect of feed on flavor in dairy foods. J. Dairy Sci. 73:3639-3650. van de Guchte, M., P. Serror, C. Chervaux, T. Smokvina, S. D. Ehrlich, and E. Maguin. 2002. Stress responses in lactic acid bacteria. Antonie van Leeuwenhoek 82:187-216.

Van Soest, P. J., J. B. Robertson, and B. A. Leis. 1991. Methods for dietary fiber, neutral detergent fiber, and non-starch polysaccharides in relation to animal nutrition. J. Dairy Sci. 74:3583-3597.

Villeneuve, M.-P., Y. Lebeuf, R. Gervais, G. F. Tremblay, J. C. Vuillemard, J. Fortin, and P. Y. Chouinard. 2013. Milk volatile organic compounds and fatty acid profile in cows fed timothy as hay, pasture, or silage. J. Dairy Sci. 96:7181-7194.

Wszołek, M., A. Y. Tamime, D. D. Muir, and M. N. Y. Barclays. 2001. Properties of kefir made in Scotland and Poland using bovine, caprine and ovine milk different starter cultures. Lebenson. Wiss. Technol. 34:251-261.

Zajšek, K., and A. Goršek. 2010. Mathematical modelling of ethanol production by mixed kefir grains yeast population as a function of temperature variations. Biochem. Eng. J. 49:7-12. 